\title{
The Possible hypo-lipidemic Effect of Aqueous Extract of Gamma-irradiated Chard Leaves in Rats Fed High Fat Diet
}

\author{
A.N. El shahat, A. M. Abdul Azeem and Ashraf M. Mounir* \\ Food Irradiation Research Department, National Centre for Radiation Research and Technology (NCRRT), Egyptian Atomic Energy \\ Authority (EAEA), P.O. Box: 29 Nasr City, Cairo, Egypt.
}

\begin{tabular}{l} 
ARTICLE INFO \\
\hline Article history: \\
Received: $4^{\text {th }}$ Nov. 2020 \\
Accepted: $5^{\text {th }}$ Apr. 2021 \\
\hline
\end{tabular}

Keywords:

Gamma-radiation,

Beta vulgaris,

high fat diet,

inflammatory factors.

\begin{abstract}
Studying the influence of gamma $(\gamma)$-rays processing on the anti-oxidant activity of chard (Beta vulgaris) leaves and implementing of the conceivable hypo-lipidemic and anti-oxidant potential of aqueous extract of $\gamma$-irradiated chard leaves (GCLAE) against high fat diet (HFD) were the two objectives of this study. Processing of dried chard leaves by $\gamma$-rays $(10 \mathrm{kGy})$ caused a significant elevation in the total phenolic content, total flavonoids, and antioxidant activity compared to the raw samples. Data showed that feeding rats HFD for 10 weeks induced a state of dyslipidemia, increase the levels of inflammatory factors, liver and cardiac markers, and also induced the level of lipid peroxidation with significant depletion of the antioxidant status relative to the control group. Supplementation of GCLAE along with HFD resulted in remarkable protection against HFD-complications and that is evidenced by reduction in total cholesterol (TC), triglycerides (TG), Low-density lipoprotein-cholesterol (LDL-C) and very Low-density lipoprotein-cholesterol(VLDL-C), remarkable increase in high-density lipoprotein cholesterol (HDL-C), tumor necrotic factor-alpha, interleukin-6, decrease the level of liver and cardiac enzymes, and also GCLAE administration enhance the activity of hepatic and cardiac antioxidant parameters (glutathione content, superoxide dismutase and catalase) and reduce the level of malondialdehyde compared to rats fed HFD. Thus, it could be concluded that $\gamma$-irradiation technique might be useful for chard processing with the purpose of shelf-life prolongation as well as to increase its antioxidant capacity. Moreover, the results concluded that GCLAE may have an effective role in reducing the health complications for those fed high fat diet.
\end{abstract}

\section{INTRODUCTION}

Feeding high fat diet is characterized by excessive fat accumulation within the body, illustrious to be a risk issue for various metabolic complications. Consumption of high-fat diet (HFD) for an extended time causes complications as oxidative stress, lipaemia, diabetes, insulin resistance, cardiovascular impairments, and some forms of cancers [1]. Prolonged feeding HFD is accompanied by high production of Reactive oxygen Species (ROS) exceeds anti-oxidant system capability of the cells resulting in incidence of lipid peroxidation, and arterial sclerosis [2]. Furthermore, HFD usually leading to a rise TC, TG and LDL-C, and a decrease in HDL-C owing to the lipogenes is paralleled by elevated messenger RNA expression and enzymatic activity of many lipogenic enzymes like fatty acid synthase, ATP- citrate lyase and levels of alcohol regulatory elementbinding protein one (SREBP-1) [3]. Some medicinal plants and natural product could have an efficient role within the treatment resulted complication of HFD and associated metabolic diseases with none side effects compared to some potent drugs employed in the obesity treatment but has side effects on the nervous system, and the cardiovascular system [1].

Chard (Beta vulgaris) is one of functional foods that considered as supplement of biologically active antioxidants phytochemical compounds that have phenolic acids, ascorbic acid, carotenoids and flavonoids that have high ability to scavenge free radicals [4]. It additionally contains a high level of many other healthpromoting compounds like minerals (iron, magnesium, calcium, phosphorus, sodium, and potassium), vitamins 
(niacin, folic acid, nourishment $\mathrm{B}_{6}$ ) and soluble fibers [5]. Moreover, it contains a highly bioactive pigments known as betalains that are synthesized from the amino acid tyrosine into 2 structural groups: yellow-orange beta-xanthins and also the red-violet betacyanins [5]. Many reports show that consumption of Beta vulgaris L. presents helpful physiological effects and may be used for the treatment of various pathologies, such as hypercholesterolemia, liver and kidney diseases, hypertension, atherosclerosis, type 2 diabetes and hematopoietic systems and dementia [4].

Vegetables and products product reptition?? are vulnerable to high levels of microorganisms throughout harvesting, transport, storage, and minimal processing. Chlorine is often used in the wash water to control the microbial population as preparing method for preparing vegetables but chlorine can't be relied on to eliminate pathogenic microorganisms [6]. Radiation processing of food and agricultural products through which the food material is subjected to electromagnetic waves like $\gamma$ rays, X-rays and electron beam accelerator, to enhance microbiological safety and stabilization. Irradiations disrupt the biological processes that lead to deterioration of food quality. It is an efficient device to decrease foodborne pathogens, spoil micro-organisms and parasites; to expand shelf-life and for disinfection from insect [7].

Therefore, the aim of this work was to determine the impact of $\gamma$-rays on the anti-oxidant activity of chard (Beta vulgaris) leaves, and the other was to explore the influence of $\gamma$-irradiated chard leaves aqueous extract (GCLAE) against feeding rats on high fat diet complications.

\section{MATERIALS AND METHODS}

Chemicals and reagents bought from Sigma Chemical Co. (St. Louis, MO, USA).

\section{Plant material}

Chard leaves were purchased from local market (Cairo, Egypt). Chard leaves were washed with tapwater and dried under shade at room temperature.

\section{Gamma Irradiation process}

Polyethylene bags filled with dried chard leaves powder subjected to10kGy of gamma- rays, using Indian Gamma Cell (Ge $4000 \mathrm{~A})^{60} \mathrm{Co}$ source at a dose rate of $1.667 \mathrm{kGy} / \mathrm{hrat}$ NCRRT, Cairo Egypt.

\section{Chard leaves extraction}

Fifty gram of $\gamma$-irradiated raw and dried chard leaves were boiled in $500 \mathrm{ml}$ distilled water for half-hour then filtered and evaporated by a rotary-evaporator under low pressure until drying. Then the extract was dissolved in distilled water before administration rats [8].

\section{Determination of anti-oxidant Content of raw and $\boldsymbol{\gamma}$ - irradiated dried chard leaves}

Total phenolic content was determined according to the Folin-Ciocalteu procedure[9] and expressed as mg of gallic acid equivalent (GAE) per $g$ of sample. Total flavonoid content was determined according to Zilicet al.[9] and expressed as mg of catechin equivalent (CE) per $g$ of sample. Determination of radical DPPH scavenging activity (Anti-oxidant activity) was determined using the stable 1, 1-Diphenyl-2-picrylhydrazyl (DPPH) according to Hwang and Do Thi[10].

\section{Animals and diet}

Animals: Twenty eight male rats (160 to $190 \mathrm{~g}$ body weight (B.WT)) were contributed in this experiment, obtained from the Egyptian Holding Company for Biological Products and Vaccines (Cairo, Egypt). Rats were adapted to controlled laboratory conditions for two weeks. Rats were kept on balanced rat diet and water that were provided ad libitum.

Table (1): Diets Composition (\%) fed to rats.

\begin{tabular}{lcc}
\hline & Control $(\%)$ & HFD $(\%)$ \\
\hline Casein & 20 & 20 \\
Starch & 58 & 15 \\
Sucrose & 5 & 15 \\
Soybean oil & 7 & - \\
Beef tallow & - & 40 \\
Cellulose & 5 & 5 \\
Vitamin-mineral & 4.5 & 4.5 \\
premix* & 0.3 & 0.3 \\
L-Cysteine & 0.2 & 0.2 \\
Choline bitartrate & &
\end{tabular}

*The mixture provides the following: Vit. A, $2000 \mathrm{IU}$; Vit. D, 200 IU; Vit.E, 10 IU; Menadione, O.5; Choline, 200; Aminobenzoic Acid, 10; Inositol, 10; Niacin, 4; Ca D-Pantothenate, 4; Riboflavin, 0.8; Thiamine. $\mathrm{HCl}, 0.5$; Pyridoxine- $\mathrm{HCl}, 0.5 ;$ Folic acid, 0.2; Biotin, 0.04; Vit.B 12 , 0.003; Glucose, To make 1000g.139.3 g NaCl; $0.79 \mathrm{~g} \mathrm{KI} ; \quad 389.0 \mathrm{~g} \mathrm{KH}_{2} \mathrm{PO}_{4} ; 57.3 \mathrm{~g} \mathrm{MgSO}$ anhyd.; $381.4 \quad g \quad \mathrm{CaCO}_{3} ; 27.0 \quad \mathrm{~g} \quad \mathrm{FeSO}_{4} .7 \mathrm{H}_{2} \mathrm{O} ; 4.01 \quad \mathrm{~g}$ $\mathrm{MnSO}_{4} \cdot \mathrm{H}_{2} \mathrm{O} ; \quad 0.548 \quad \mathrm{~g} \quad \mathrm{ZnSO}_{4} .7 \mathrm{H}_{2} \mathrm{O} ; 0.477 \quad g$ $\mathrm{CuSO}_{4} .5 \mathrm{H}_{2} \mathrm{O}$; and $0.023 \mathrm{~g} \mathrm{CoCl}_{2} .6 \mathrm{H}_{2} \mathrm{O}$ 


\section{Experimental design}

Four groups each group contain 7 rats

Group 1 (C group): Control rats fed with normal pellet diet for 10 weeks (Table 1).

Group 2 (HFD group): Rats fed with HFD for 10 weeks (Table 1).

Group 3 (HFD\&RCLAE): Rats fed with HFD plus raw chard leaves aqueous extract (RCLAE) (250 $\mathrm{mg} / \mathrm{kg}$ B.WT./day/10 weeks) [11] by gavage through an intra-gastric tube.

Group 4 (HFD\&GCLAE): Rats fed with HFD plus $\gamma$ irradiated-chard leaves aqueous extract (GCLAE) $(250 \mathrm{mg} / \mathrm{kg}$ B.WT./day/10 weeks) by gavage feeding through an intra-gastric tube.

Each rat was weighted at the beginning and at the end of experimental period. Ten weeks later, rats were fasted for 24 hours and anaesthetized with diethyl ether. Blood sample were gathered through heart puncture and let to clot and centrifuged to obtain serum to perform biochemical analysis.

\section{Biochemical Analysis}

TC, TG and HDL-C were estimated according to procedure described by Allain [12], Fossati and Prencipe [13] and Demacker [14], respectively. LDL-C and VLDL-C were estimated according to Friedwald's formula [15] by the following equations: LDL-C $(\mathrm{mg} / \mathrm{dl})$ $=\mathrm{TC}-(\mathrm{TG} / 5+\mathrm{HDL}-\mathrm{C})$, VLDL $(\mathrm{mg} / \mathrm{dl})=\mathrm{TG} / 5$. The levels of lactate dehydrogenase (LDH) and creatine phosphokinase (CPK) were determined by the method of King [16]. Creatinine kinase-MB (CK-MB) and cardiac troponin I (cTnI) were performed by ELISA technique (BioSource International, Camarillo, CA, USA) according to the manufacturer's instructions. The activity of serum aspartate transaminase (AST) and alanine transaminase (ALT) was evaluated according to Reitman and Frankel [17], serum $\gamma$-glutamyltransferase (GGT) was estimated according to Rosalki [18] and serum alkaline phosphatase activity (ALP) was evaluated according to Kind and King [19]. Serum tumor necrotic factor-alpha (TNF- $\alpha$ ) and interleukin-6 (IL-6) was performed by ELISA technique using rats kits (BioSource International, Camarillo, CA, USA) according to the manufacturer's instructions. The concentration of malondialdehyde (MDA) was determined according to Yoshioka [20], GSH content was determined by Beutler [21], superoxide dismutase activity (SOD) was measured by Minami and Yoshikawa [22] and Catalase activity (CAT)by Johansson and Borg [23].

\section{Statistical analysis}

Results were analyzed using one way analysis of variance and Duncan's multiple range tests by computer program SPSS [24] and represented as mean \pm SE $(n=7)$ $(\mathrm{P}<0.05)$.

\section{RESULTS}

Data in Table (2) mentioned that irradiation increased the total phenols content, total flavonoids and antioxidant activity of raw dried chard leaves by percent change $4.9 \%, 7.5 \%$ and $4.5 \%$, respectively.

Table (2): Total phenols, total flavonoids and anti-oxidant activity content of raw and $\gamma$-irradiated dried chard leaves

\begin{tabular}{|c|c|c|c|}
\hline \multirow{2}{*}{ Parameters } & \multicolumn{2}{|c|}{ chard leave powder } & \multirow{2}{*}{$\begin{array}{c}\% \\
\text { Change }\end{array}$} \\
\hline & Raw & Irradiated & \\
\hline $\begin{array}{l}\text { Total phenolic content } \\
(\mathrm{mg} \text { GAE/g DW } \pm \text { S.D) }\end{array}$ & $4.88 \pm 0.28$ & $5.12 \pm 0.31$ & $4.9 \%$ \\
\hline Total Flavonoids (CE mg/g) & $4.92 \pm 0.26$ & $5.29 \pm 0.29$ & $7.5 \%$ \\
\hline DPPH (AAE mg/g) & $4.21 \pm 0.23$ & $4.40 \pm 0.25$ & $4.5 \%$ \\
\hline
\end{tabular}

Values are means of three replicates $( \pm S D)$

Feeding HFD raised the serum levels of TC, TG, LDL-C and vLDL-C with remarkable diminution in HDL-C compared to control group. Then tested parameters diminish by treatment of HFD-rats with either RCLAE or GCLAE (Table 3).

Table (3): Effect of supplementation with RCLAE and GCLAE on lipid contents in rats fed with HFD

\begin{tabular}{lcccc}
\hline \multicolumn{1}{c}{ Parameters } & C & HFD & HFD\&RCLAE & HFD\&GCLAE \\
\hline TC (mg/dl) & $161.12 \pm 3.37^{\mathrm{c}}$ & $256.26 \pm 5.62^{\mathrm{a}}$ & $191.11 \pm 4.63^{\mathrm{b}}$ & $184.67 \pm 4.28^{\mathrm{b}}$ \\
TG (mg/dl) & $111.55 \pm 3.05^{\mathrm{c}}$ & $201.26 \pm 3.71^{\mathrm{a}}$ & $144.18 \pm 2.72^{\mathrm{b}}$ & $140.36 \pm 2.62^{\mathrm{b}}$ \\
HDL-C (mg/dl) & $45.18 \pm 1.85^{\mathrm{a}}$ & $33.68 \pm 1.29^{\mathrm{c}}$ & $40.92 \pm 1.40^{\mathrm{b}}$ & $41.38 \pm 1.56^{\mathrm{b}}$ \\
LDL-C (mg/dl) & $93.63 \pm 3.56^{\mathrm{c}}$ & $182.33 \pm 4.68^{\mathrm{a}}$ & $121.13 \pm 3.96^{\mathrm{b}}$ & $115.22 \pm 3.83^{\mathrm{b}}$ \\
vLDL-(mg/dl) & $22.31 \pm 1.48^{\mathrm{c}}$ & $40.25 \pm 1.85^{\mathrm{a}}$ & $28.84 \pm 1.56^{\mathrm{b}}$ & $28.07 \pm 1.44^{\mathrm{b}}$ \\
\hline
\end{tabular}


Table (4) illustrate that HFD induced remarkableelevation in the levels of inflammatory factors (TNF- $\alpha$ and IL-6), liver and cardiac markers (ALP, $\gamma \mathrm{GT}, \mathrm{ALT}, \mathrm{AST}, \mathrm{LDH}, \mathrm{CK}-\mathrm{MB}$ and cTnI) in HFD-rats relative to the control group. Supplementation of HFD-rats with RCLAE and GCLAE caused significant reduction in the levels of TNF- $\alpha$, IL-6, ALP, $\gamma \mathrm{GT}, \mathrm{ALT}, \mathrm{AST}, \mathrm{LDH}, \mathrm{CK}-\mathrm{MB}$ and cTnI compared to rats fed with HFD.
The results in Table (5) indicated that induced hyperlipidemia in HFD-rats caused significant elevation in the level of hepatic and cardiac MDA accompanied by reduction in the GSH level and the SOD activity and CAT relative to control group. Whereas, rats received HFD along with RCLAE or GCLAE exhibited higher level of anti-oxidant contents and lower MDA level than the group received HFD only.

Table (4): Effect of supplementation with RCLAE and GCLAE on biochemical parameters levels in rats fed with HFD

\begin{tabular}{|c|c|c|c|c|}
\hline Parameters & $\mathbf{C}$ & HFD & HFD\&RCLAE & HFD\&GCLAE \\
\hline TNF- $\alpha(p g / m L)$ & $668.74 \pm 48.62^{c}$ & $896.65 \pm 59.24^{\mathrm{a}}$ & $692.36 \pm 44.62^{b}$ & $689.12 \pm 45.81^{b}$ \\
\hline IL-6 (pg/mL) & $333.65 \pm 28.65^{c}$ & $476.58 \pm 36.57^{a}$ & $381.37 \pm 31.22^{\mathrm{b}}$ & $369.41 \pm 25.27^{b}$ \\
\hline LDH (U/ml) & $231.18 \pm 14.25^{\mathrm{c}}$ & $455.63 \pm 21.37^{\mathrm{a}}$ & $329.94 \pm 18.65^{\mathrm{b}}$ & $320.28 \pm 19.12^{b}$ \\
\hline CPK (U/L) & $266.23 \pm 8.52^{c}$ & $471.63 \pm 12.15^{\mathrm{a}}$ & $328.89 \pm 10.17^{\mathrm{b}}$ & $319.88 \pm 11.10^{\mathrm{b}}$ \\
\hline CK-MB(ng/mL) & $3.19 \pm 0.73^{c}$ & $7.37 \pm 1.15^{\mathrm{a}}$ & $5.72 \pm 0.96^{b}$ & $5.59 \pm 0.94^{b}$ \\
\hline CTnI (ng/mL) & $25.83 \pm 1.32^{\mathrm{c}}$ & $68.928 \pm 3.16^{\mathrm{a}}$ & $40.39 \pm 2.54^{\mathrm{b}}$ & $38.97 \pm 2.68^{b}$ \\
\hline AST (U/ml) & $37.15 \pm 1.82^{c}$ & $58.56 \pm 2.25^{\mathrm{a}}$ & $42.14 \pm 2.16^{b}$ & $41.67 \pm 1.63^{b}$ \\
\hline ALT (U/ml) & $25.77 \pm 1.37^{\mathrm{c}}$ & $40.42 \pm 1.96^{\mathrm{a}}$ & $32.47 \pm 0.92^{\mathrm{b}}$ & $31.55 \pm 0.82^{b}$ \\
\hline $\mathbf{A L P}(\mathbf{U} / 100 \mathrm{ml})$ & $7.96 \pm 0.68^{c}$ & $15.12 \pm 0.84^{\mathrm{a}}$ & $10.87 \pm 0.74^{b}$ & $10.26 \pm 0.77^{b}$ \\
\hline$\gamma \mathbf{G T}(\mathbf{U} / \mathbf{m l})$ & $4.72 \pm 0.58^{\mathrm{c}}$ & $7.05 \pm 0.71^{\mathrm{a}}$ & $5.66 \pm 0.62^{\mathrm{b}}$ & $5.29 \pm 0.58^{b}$ \\
\hline
\end{tabular}

Table (5): Effect of supplementation with RCLAE and GCLAE on hepatic and cardiac lipid peroxidation and anti-oxidant status in rats fed with HFD

\begin{tabular}{|c|c|c|c|c|c|}
\hline Parameters & & $\mathbf{C}$ & HFD & HFD\&RCLAE & HFD\&GCLAE \\
\hline \multirow{2}{*}{$\begin{array}{c}\text { MDA } \\
\text { (n mol/g tissue) }\end{array}$} & Liver & $215.42 \pm 4.75^{\mathrm{c}}$ & $364.32 \pm 6.24^{\mathrm{a}}$ & $272.56 \pm 5.13^{b}$ & $266.75 \pm 5.28^{\mathrm{b}}$ \\
\hline & Heart & $130.11 \pm 4.24^{\mathrm{c}}$ & $229.85 \pm 5.57^{\mathrm{a}}$ & $171.55 \pm 4.62^{\mathrm{b}}$ & $165.72 \pm 4.53^{b}$ \\
\hline \multirow{2}{*}{$\begin{array}{c}\text { GSH } \\
\text { (mg/g tissue) }\end{array}$} & Liver & $31.16 \pm 0.79^{\mathrm{a}}$ & $17.56 \pm 0.62^{\mathrm{c}}$ & $27.43 \pm 0.78^{b}$ & $29.75 \pm 0.82^{\mathrm{ab}}$ \\
\hline & Heart & $5.17 \pm 0.21^{\mathrm{a}}$ & $2.65 \pm 0.26^{c}$ & $3.77 \pm 0.23^{b}$ & $4.96 \pm 0.29^{\mathrm{a}}$ \\
\hline \multirow{2}{*}{$\begin{array}{c}\text { SOD } \\
\text { (U/mg protein) }\end{array}$} & Liver & $48.36 \pm 0.96^{\mathrm{a}}$ & $27.86 \pm 0.82^{\mathrm{c}}$ & $40.35 \pm 0.87^{b}$ & $41.15 \pm 0.78^{b}$ \\
\hline & Heart & $27.86 \pm 1.34^{\mathrm{a}}$ & $17.63 \pm 0.95^{\mathrm{c}}$ & $22.72 \pm 1.13^{\mathrm{b}}$ & $23.16 \pm 1.24^{\mathrm{b}}$ \\
\hline \multirow{2}{*}{$\begin{array}{c}\text { CAT } \\
\text { (U/mg protein) }\end{array}$} & Liver & $51.11 \pm 1.73^{\mathrm{a}}$ & $34.28 \pm 1.03^{\mathrm{c}}$ & $44.46 \pm 1.17^{b}$ & $45.26 \pm 1.14^{\mathrm{b}}$ \\
\hline & Heart & $40.31 \pm 1.22^{\mathrm{a}}$ & $23.84 \pm 1.16^{\mathrm{c}}$ & $31.25 \pm 1.24^{\mathrm{b}}$ & $32.16 \pm 1.33^{\mathrm{b}}$ \\
\hline
\end{tabular}




\section{DISCUSSION}

Feeding HFD for a long time may lead to the progression of diseases related to fatty liver such as nonalcoholic fatty liver disease, diabetes mellitus, Circulatory disorders such as heart failure and coronary heart disease [25]. Chard (Beta vulgaris) has widespread use in traditional medicine as a strong anti-oxidant, antiacetyl-cholinesterase, anti-diabetic, anti-tumor and hepato protective agent because it contains various natural components, such as carotenoids, some fatty acids, phospholipids, glycolipids, polysaccharides, folic acid, vitamins $\mathrm{C}$ and $\mathrm{E}$, and poly-phenolic and thiol (SH) compounds [26].

The results showed that the use of irradiation technique play an important role in increasing the efficiency and quality of chard by an elevation the total phenol and flavonoids content and the anti-oxidant activity. Latorre [27] concluded that irradiation produced bio-chemical changes as an increase in reducing power of red beet extract and showing that irradiation could be used in combination with other techniques for red beet processing. As, reported by Kumari [28] $\gamma$-irradiation may contributed to increase the total phenolic content by degradation of large phenolic complex to small molecules which facilitate the release of active ingredients. El Shahat [29] mentioned that radiation processing could be effective in increasing the total phenolic contents of irradiated basil leaves compared with raw ones by inducing the decomposition of some insoluble phenolic compounds.

In this research, it was obtained that HFD consumption resulted in hyper-lipidemic changes. These results are in conformity with that of Noeman [30] and Suganya [31], Lavie and Milani [32] reported that feeding rats on HFD causes significant changes in lipid profile, these changes appeared in the rise of TC, TG and phospholipids and down regulation in HDL-C. It was found that elevation of TG resulting from high fat diet could be related to enhancing liver VLDLtriglyceride secretion into circulation [33]. Addition of RCLAE or GCLAE along with HFD ameliorated the hyperlipidemic effect of HDF, this may be due to the bioactive contents flavanoids and saponins present in chard leaves [11] and [34]. The down regulation effect of chard leave extract of both TC and TG can be attributed to the high content of saponins [11].

Several studies show that long-term consumption of the high fat food can lead to health complications accompanied by chronic inflammation and emergence of oxidative stress in patients [35]. In the current work the levels of TNF- $\alpha$ and IL- 6 were significantly up-regulated by HFD consumption compared with control rats. Obesity due to HFD intake induced excessive release of free fatty acids into blood circulation that can lead to inflammation characterized by over production of pro inflammatory adipo-cytokines such as IL-6 and TNF $\alpha$ [36]. Meliet [37] observed that Feeding rats HFD for long time led to increase expression of inflammatory factors mRNA such as IL- 6 and TNF- $\alpha$ due to increase liver tissue damage. On the other hand, results of rats treated with RCLAE or GCLAE along with HFD intake are in agreement with those of El Gamal [38] who found that rats fed chard had lower concentrations of proinflammatory mediators, such as Il-6, TNF- $\alpha$, myeloperoxidase and the transcription factor NF- $\mathrm{kB}$. The down regulation of these cytokines could be attributed to betalains present in Chard significantly inhibits NF- $\mathrm{kB}$ and also markedly suppress cyclooxygenase-2 (COX-2) expression which is an important precursor molecule for prostaglandins [39].

The results in this study suggested that HFD induced disturbances in both liver and cardiac functions when compared with control rats in agreement with those of Amin and Nagy [40] who postulated that presence of extra FFA's in portal blood could cause inflammation within hepatic cells, and furthermore release proinflammatory cytokines, leading to more hepatocyte injury, and affecting the liver cell's permeability with over releasing of hepatic enzymes to the blood stream, these was elucidated by Suanarunsawat [41] informed that, elevation cholesterol diet markedly impaired liver and cardiac functions as expressed by an increase of serum levels of AST, ALT, LDH and CK-MB activities. By increasing obesity, the muscle mitochondrial content function was reduced which would result in increased mitochondrial volume, and increased glycolytic enzymes leading to increase activity of $\mathrm{CK}$, as this enzyme is responsible for rapidly transferring high-energy phosphate groups from the site of production to the site of use [42]. 
The hepatic and cardiac protective effects of chard leaves aqueous extract were observed in the group of rats fed HFD along with either RCLAE or GCLAE compared to HFD-group. Jain and Singhai [43] mentioned that Chard could maintain the functional integrity of hepatocyte membrane, thus protecting the hepatocytes against ethanol toxicity and was also found to be effective in decreasing the leakage of ALT and LDH triggered by ethanol. Yang [44] showed that betanin, a kind of water-soluble nitrogen pigment found in Chard, improved cardiac function, and effectively inhibited CK, CK-MB, cTnT and LDH activities in isoproterenolinduced acute myocardial infarction.

The data of the present work showed that HFD caused an increase in the level of lipid peroxidation product, malondialdehyde (MDA) and reduced the activity of both hepatic and cardiac tissues enzymatic anti-oxidant defense system [30]. HFD resulted in over production of Reactive oxygen species (ROS) and lipid peroxidation products impaired the respiratory chain in hepatocytes either directly or indirectly through oxidative damage to the mitochondrial genome. Mitochondrial dysfunction can also lead to apoptosis or necrosis depending on the energy status of the cell [30].Vincent [45] reported that the HFD caused increase in lipid precipitation in the myocardium which performs a good substrate for lipid peroxidation in cardiac tissue by free radicals. Rat fed on HFD with RCLAE or GCLAE results agrees with Hamdiken and Kechrid [46] who concluded that chard played a positive role in decreasing MDA levels and increasing the GSH levels in rats exposed to ethanolic toxicity. The anti-oxidant and free radical-scavenging activities of chard could be attributed to its active components such as phenolic contents, flavonoid, glycosides and saponins [4]. Also, the amino acid proline, one of chard components, is considered one component of intracellular defense system against oxidative stress caused by free radicals and ROS [47].

\section{CONCLUSION}

This study is showing that $\gamma$-irradiation of chard increases its anti-oxidant capacity and that might be useful to use this technique in the frame ???for chard processing with the purpose of shelf-life prolongation. As a result of all the biochemical findings obtained, this study demonstrates the bioavailability of GCLAE in the event of hepatic and cardiac damage due to HFD. The effectiveness of GCLAE against HFD could be due to presence of the total flavonoids and total phenols, amino acid proline and the bioactive pigments betalains that can enhance the anti-oxidant status, scavenge the free radicals and reduced the lipid peroxidation.

\section{REFERENCES}

[1] Tuzcu,Z., Orhan,C., Sahin,N., Juturu,V.and Sahin, K. (2017). Cinnamon Polyphenol Extract Inhibits Hyperlipidemia and Inflammation by Modulation of Transcription Factors in High-Fat Diet-Fed Rats. Oxid Med Cell Longev. 2017; 2017: 1583098.

[2] Farhangi, M. A., Nameni, G., Hajiluian, G. and Mesgari-Abbasi, M. (2017). Cardiac tissue oxidative stress and inflammation after vitamin D administrations in high fat- diet induced obese rats. BMC Cardiovascular Disorders 17:161.

[3] Ruiz, R., Jideonwo, V., Ahn, M., Surendran, S., Tagliabracci,V.S., Hou, Y., Gamble, A., Kerner, J., Irimia-Dominguez, J.M., Puchowicz, M.A., DePaoli-Roach, A., Hoppel, C., Roach,P.and Morral, N. (2014).Sterol regulatory elementbinding protein-1 (SREBP-1) is required to regulate glycogen synthesis and gluconeogenic gene expression in mouse liver.JBiol Chem. 2014 Feb 28; 289 (9):5510-7.

[4] Hajihosseini, S, Setorki, M, and Hooshmandi, Z. (2017). The antioxidant activity of Beta vulgaris leaf extract in improving scopolamine-induced spatial memory disorders in rats. Avicenna $\mathrm{J}$ Phytomed 2017 Epub.

[5] Al Nouri, D. M., Althalmawi, H. O., Al Faifi, L. Y., Al Owayedh, H. M. and Arzoo S. (2017).Study on the growth factors and hepatoprotective effect of Beta vulgaris L. in male Wistar rats IJRDO-Journal of Health Sciences and Nursing , 2 (1):18-27.

[6] Pan, Xiaojun and Nakano, Hiroyuki (2014).Effects of Chlorine-Based Antimicrobial Treatments on the Microbiological Qualities of Selected Leafy Vegetables and Wash Water. Food Science and Technology Research, 20 (4): 765774

[7] Ahmad, S. M., Mir, A. S. and Pala, A. S. (2014). Enhancing food safety and stability through irradiation: A Review. J. Microbial Biotech Food Sci, 3(5): 371-378. 
[8] Ozlem, Ozsoy-S. O.,Karabulut-B., Sehnaz,B., Refiye,Y. and Yasemin,O. (2004). Effects of Chard (Beta vulgaris L. varcicla) on the Liver of the Diabetic Rats: A Morphological and Biochemical Study, Bioscience, Biotechnology, and Biochemistry, 68(8):1640-1648.

[9] Zilic, S., Serpen, A., Akýllýoglu, G., Jankovic, M. and Gökmen, V. (2012).Distributions of phenolic compounds, yellow pigments and oxidative enzymes in wheat grains and their relation to antioxidant capacity of bran and debranned flour. Journal of Cereal Science, 56: 652-658.

[10] Hwang, E.S. and Do Thi N. (2014).Effects of extraction and processing methods on antioxidant compound contents and radical scavenging activities of Laver (Porphyratenera). Prev. Nutr. Food Sci., 19: 40-48.

[11] Al-Dosari, M., Alqasoumi, S., Ahmad, M. , AlYahya, M., Ansari, M. N. and Syed R. (2011). Effect Of Beta Vulgaris L. On Cholesterol Rich Diet-Induced Hypercholesterolemia In Rats. FARMACIA, 59(5):669-677.

[12] Allain, C. C., Poon, L. S., Chan, C. S., Richmond, W. and Fu, P. C. (1974). Enzymatic determination of total serum cholesterol.Clin.Chem.20, 470.

[13] Fossati, P. and Prencipe, L. (1982). Serum triglycerides determined calorimetrically with an enzyme that produce hydrogen peroxide. Clin. Chem., 28:2077.

[14] Demacker, P. N. , Vos-Janssen, H. E. , Hifmans, A. G. M. , Van'tLaar, A. and Jansen, A. P. (1980). Measurement of high- density lipoprotein cholesterol in serum: Comparison of six isolation methods combined with enzymatic cholesterol analysis. Clin. Chem., 26:1780.

[15] Friedwald, W.T., Levy, R. I. and Fredrickson, D. (1972).Estimation of concentration of low-density lipoprotein cholesterol in plasma without use of the preparative ultra-centrifuge. Clin Chem. 18(6):499.

[16] King, J. (1965) (ed). The dehydrogenases or oxido reductases - lactate dehydrogenase. In: Practical Clinical Enzymology. Van Nostrand Company Ltd, London, 83-93.
[17] Reitman, S. and Frankel, S. (1957).A calorimetric method for the determination of serum glutamic oxalacetic and glutamic pyruvic transaminases. Am. J. Clin. Pathol .28: 56.

[18] Rosalki, S.B.(1975).Gamma glutamyltranspeptidase. Advclin Chem. 17:53-107.

[19] Kind, P. and King E. (1954). Estimation of plasma phosphatase by determination of hydrolysed phenol with amino antipyrine. J Clin Pathol 7: 322.

[20] Yoshioka, T., Kawada, K., Shimada, T. and Mori, M. (1979).Lipid peroxidation in maternal and cord blood and protective mechanism against activated-oxygen toxicity in the blood. Am J Obstet Gynecol. 135: 372-376.

[21] Beutler, E., Duron, O. and Kelly, B.M. (1963). Improved method for the determination of blood glutathione. J Lab Clin Med. 61: 882-888.

[22] Minami, M. and Yoshikawa, H. (1979).A simplified assay method of superoxide dismutase activity for clinical use.Clin.Chim.Acta., 92: 337342.

[23] Johansson, L.H. and Borg, L.A.H. (1988).A spectrophotometric method for determination of catalase activity in small tissue samples.Anal.Biochem.74: 331.

[24] SPSS.(1998).Statistical Package for Social Science. Computer Software, Ver. 10. SPSS Company, London, UK.

[25] Bhandari, U., Kumar, V., Khanna, N. and Panda, B. P. (2012).The effect of high-fat diet-induced obesity on cardiovascular toxicity in wistar albino rats. Human and Experimental Toxicology 30(9): 1314- 1321.

[26] Ustundag, U. V., Tunali, S., Alev, B., Ipekci, H., Emekli-Alturfan, E., Akbay T. T., Yanardag, R. and Yarat, A.(2016).Effects of Chard (Beta Vulgaris L. Var. Cicla) On Cardiac Damage In Valproic Acid-Induced Toxicity. Journal of Food Biochemistry,40: 132-139 VC 2015 Wiley Periodicals, Inc1

[27] Latorre, M. E., Narvaiz, P., Rojas, A. M. and Gerschenson, L.N. (2010).Effects of $\gamma$ - irradiation on bio-chemical and physico-chemical parameters of fresh-cut red beet (Beta vulgaris L. var. 
conditiva) root. Journal of Food Engineering 98:178-191.

[28] Kumari, N., Kumar P., Mitra D., Prasad B., Tiwary B. N. and Varshney L. (2009). Effects of Ionizing Radiation on Microbial Decontamination, Phenolic Contents, and Antioxidant Properties of Triphala.Journal of Food Science. 74(3): M109M1113.

[29] El Shahat, A.N., El-Shennawy, H.M. and Mohamed, H.M. Abd el-Megid (2017).Studying the protective effect of $\gamma$-irradiated basil (OcimumbasilicumL.) against methotrexateinduced liver and renal toxicity in rats. Indian $\mathrm{J}$. Anim. Res., 51 (1): 135-140.

[30] Noeman, S. A., Hamooda, H. E. and Baalash A. A. (2011). Biochemical Study of Oxidative Stress Markers in the Liver, Kidney and Heart of High Fat Diet Induced Obesity in Rats. Diabetology\& Metabolic Syndrome 3:17.

[31] Suganya, V., Vetriselvan, S., Velmurugan, C. and Sarath, C. (2016). Anti-oxidant and Antihyperlipidemic activity of Hemidesmusindicus in rats fed with high-fat diet.Avicenna J Phytomed 6 (5): 516-525.

[32] Lavie, C.J. and Milani, R.V. (2003). Obesity and cardiovascular disease: hippocrates paradox? J Am CollCardiol 42: 677-679.

[33] Contreras, R. J. and Williams, V. L. (1989). Dietary obesity and weight cycling: effects on blood pressure and heart rate in rats. The American Journal of Physiology: Regulatory Integrative and Comparative Physiology, 256(6): R1209-R1219.

[34] Zeineb, M., Hassiba, C., Yasmine, C., Montaña, C. and Hatem, M. (2019). Wild edible Swiss chard leaves (Beta vulgaris L. var. cicla): Nutritional, phytochemical composition and biological activities Food Research International, 119 : 612621.

[35] Wu, Zhang F., Dai, Y., Han, L. and Chen, S. (2016). Serum TNF-a, GTH and MDA of high-fat diet-induced obesity and obesity resistant rats Peixian. Saudi Pharmaceutical Journal 24: 333336.

[36] Soto-Vaca, A., Losso, J.N., McDonough, K. and Finley, J.W. (2013).Differential effect of 14 free fatty acids in the expression of inflammation markers on human arterial coronary cells. J Agric Food Chem: 6110074-6110079.

[37] Meli, R., Mattace-Raso, G., Irace, C., Simeoli,,R., Di Pascale, A., Paciello, O., Pagano, T. B., Calignano, A., Colonna, A. and Santamaria, R. (2013). High Fat Diet Induces Liver Steatosis and Early Dysregulation of Iron Metabolism in Rats. PLoS ONE 8(6): e66570.

https://doi.org/10.1371/journal.pone.0066570

[38] El Gamal, A.A.,AlSaid, M.S.,Raish, M., alSohaibani, M., al-Massarani, S.M., Ahmad, A.,Hefnawy, M., al-Yahya, M.,Basoudan, O.A. and Rafatullah, S. (2014). Beetroot (Beta vulgaris L.) extract ameliorates gentamicin-induced nephrotoxicity associated oxidative stress, inflammation, and apoptosis in rodent model. Mediat.Inflamm.2014: 983-952.

[39] Clifford, T., Howatson, G., West, D. J. and Stevenson, E. J. (2015). The Potential Benefits of Red Beetroot Supplementation in Health and Disease Nutrients 7:2801-2822.

[40] Amin, K. A. and Nagy, M. A. (2009). Effect of Carnitine and herbal mixture extract on obesity induced by high fat diet in rats. Diabetology \& Metabolic Syndrome 1:17.

[41] Suanarunsawat, T., Ayutthaya, W.D., Songsak, Thirawarapan, S.and Poungshompoo, S. (2011). Lipid-lowering and antioxidative activities of aqueous extracts of Ocimum sanctum L. leaves in rats fed with a highcholesteroldiet.Oxid Med Cell Longev.962025.

[42] Janssen, E., Terzic A., Wieringa B. and Dzeja P.P. (2003).Impaired intracellular energetic communication in muscles from creatine kinase and adenylate kinase (M-CK/AK1) double knockout mice. J BiolChem 278:30441-9.

[43] Jain, N.K. and Singhai A. K. (2012).Protective Role of Beta Vulgaris L. Leaves extract and fractions On Ethanol-Mediated Hepatic Toxicity.ActaPoloniaePharmaceutica N Drug Research 69(5): 945-950.

[44] Yang, B., Cao, F., Zhao, H., Zhang J., Jiang, B. and Wu,Q. (2016).Betanin ameliorates isoproterenol-induced acute myocardial infarction through iNOS, inflammation, oxidative stressmyeloperoxidase/low-density lipoprotein in rat Int J ClinExpPathol 9(3):2777-2786.

Arab J. Nucl. Sci. Appl., Vol. 54, 3, (2021) 
[45] Vincent, H.K., Powers, S.K., Dirks, A.J. and Scarpace, P. (2001). Mechanism for obesity induced increase in myocardial lipid peroxidation. Int J Obes 2001, 25:378-378.

[46] Hamdiken, M. and Kechrid, Z.(2017).Chard (BETA VULGARIS VAR. CICLA) Extractmodulates zinc status, glucose levels and antioxidant values in diabetic rats fed zinc deficiency diet, Int J Pharm PharmSci, 9, (10): 297-304

[47] Unsal, V. U., Sevim, T. ,Burcin, A. , Hazal, I. , EbruEmekli-Alturfan, Tugba, T., Refiye, Y. and Aysen, Y. (2016), Effectsof chard (Beta Vulgaris L. Var. Cicla) on cardiac damage in valpoic acidinduced toxicity., Journal of Food Biochemistry 40 : 132-139. 